\title{
Tribunais de Sangue de San Fernando. o Sentido Político-Social do Terror Lopizta
}

Blood Courts of San Fernando. The political and social sense of the terror of López

Tribunales de sangre de San Fernando. El sentido político-social del terror Lopizta

Mário Maestri

\section{Resumo}

A grande conspiração contra a continuidade da guerra, descoberta e reprimida no acampamento de San Fernando, em meados de 1868, é apresentada tradicionalmente como produto da imaginação paranoica do mariscal, por seus detratores, e justificada por seus defensores, apesar do caráter sumário dos julgamentos, sem direito à defesa, e do amplo uso da tortura. $\mathrm{O}$ artigo apresenta interpretações sobre o sentido social da indiscutível conspiração organizada em torno da família López e da dura repressão que ela motivou.

Palavras-chave: Guerra do Paraguai. Terror e política. Tribunais de Sangue de San Fernando.

\section{Da guerra ofensiva à luta pela independência nacional}

A imprensa internacional contemporânea à guerra e, mais tarde, a historiografia especializada destacaram a duríssima repressão ordenada por Solano López, a partir de meados de 1868, contra dignitários do Estado, diplomatas, estrangeiros e membros das classes dominantes paraguaias acusados de traição. Esses sucessos foram referidos em geral como "Los tribunales de sangre de San Fernando". ${ }^{1}$

Os processos sumários dos acusados nos tribunais de San Fernando e nos sucessos posteriores teriam levado à execução em

\footnotetext{
Doutor em Ciências Históricas pelo Université Catholique de Louvain, Bélgica. Professor Titular da Universidade de Passo Fundo.
}

Recebido em 10/09/2012 Aprovado em 20/01/2013 http://dx.doi.org/10.5335/hdtv.13n.1.3047 
torno de uns quatrocentos ou mais prisioneiros. Na instrução das acusações, utilizou-se ampla e explicitamente a tortura física - açoites, marteladas, a temida uruguayana etc. As mortes de prisioneiros, em geral do sexo masculino, devido aos maus-tratos elevariam-se a meio milhar. ${ }^{2}$

Em geral, ignorando fatos históricos inquestionáveis, o lopizmo negativo negou a própria existência da conspiração contra o prosseguimento da resistência, propondo que a repressão se deveria aos delírios paranoicos ou persecutórios do mariscal. Serviu-se da repressão de San Fernando, comumente extremando o número dos vitimados além do imaginável, para consolidar as propostas apologéticas sobre a guerra como produto do mero "despotismo" e de suplícios produzidos pela "cruel ferocidad" de Solano López. ${ }^{3}$

Ao contrário, interpretações históricas do lopizmo positivo justificaram e minoraram a dureza e a extensão da repressão, enfatizando axiomaticamente a existência da conspiração e apresentando o uso da tortura como recurso legal, permitido pela legislação judiciária paraguaia. ${ }^{4}$ Ambas versões pouco exploraram o sentido político-social da conspiração e da repressão subsequente, assim como as consequências de uma e de outra.

\section{Comércio ou morte}

As expedições militares paraguaias nas províncias brasileiras do Mato Grosso e do Rio Grande e na província argentina de Corrientes teriam contado com o apoio dos comerciantes, dos estancieiros, do alto clero, da oficialidade do exército etc., segmentos sociais fortemente espanholizados e concentrados em Asunción. Esse bloco político-social dominante dependia da manutenção-ampliação do comércio mundial, objetivo perseguido pelo lopizmo desde sua instauração, em 1842.

Com a hegemonia liberal unitária argentina sobre o porto de Buenos Aires, a intervenção imperial no Uruguai e o controle do porto de Montevidéu permitiriam o fechamento discricionário dos contatos marítimos internacionais paraguaios. Uma vitória militar paraguaia na guerra consolidaria a posição mercantil do país e aceleraria o fortalecimento já em curso das classes proprietárias, em desfavor dos segmentos sociais camponeses paraguaios.

Porém, não é impossível igualmente que, desde o início do conflito, setores das classes proprietárias vissem na guerra uma possibilidade de desfazer-se de regime que concentrava em forma discricionária nas mãos da família López o poder político e as melhores possibilidades de enriquecimento. Não seriam poucos os descontentes com a importante interferência do Estado na economia e com os limites postos ao liberalismo econômico no país.

Em 16 de março de 1865, o cónsul francês Émile Laurent-Cochelet [1843-1888], duro crítico do lopizmo, registrava sobre as celebrações oficiais em Asunción referentes ao início do conflito: "Aquellos que se asocian más ostentosamente a las manifestaciones a favor del Paraguay y en contra del Brasil, son quizá los que mayor odio y antipatía sienten por el régimen actual, y quienes hacen en secreto los votos más fervientes para su derrocamiento". ${ }^{5}$ Salvo engano, não 
contamos ainda com estudos mais detidos sobre a oposição-dissidência ao lopizmo, no interior do país, entre as classes dominantes nos momentos anteriores à guerra.

\section{As classes silenciadas}

Apesar de o governo paraguaio ter procurado conquistar o apoio das classes camponesas de origem guarani, elas não foram minimamente consultadas sobre a intervenção no Prata. As classes populares haviam sido afastadas institucionalmente da gestão política do Estado pelas reformas eleitorais de Carlos Antonio López sobre a designação de deputados nacionais. O congresso que aprovou a guerra representou essencialmente os grandes proprietários do país.

Sem interesses no comércio internacional, o campesinato opusera-se desde os tempos coloniais às operações militares exteriores, que monopolizavam a força de trabalho rural, desorganizando uma produção familiar orientada para a subsistência e para o comércio local. A constituição de um exército profissional por José Gaspar Rodrigues de Francia cumprira uma velha reivindicação dos segmentos rurais.

A "liberação" do saque, por Solano López, durante a invasão do Rio Grande , parece ter sido também meio de manter o consenso relativo de soldados-camponeses envolvidos em operações que não eram de seu interesse e durante as quais não receberam soldo, à exclusão de raras gratificações. ${ }^{6}$ A baixa belicosidade durante a campanha expedicionária, com destaque para a rendição de Uruguaiana, teria registrado a adesão superficial da tropa àquelas operações.
Em 28 de agosto de 1865, o jovem capitão argentino "Dominguito" Sarmiento escreveu à sua mãe propondo que, após o combate de Yatay, ficara "asegurado que los paraguayos" não eram "enemigos dignos" dos aliancistas. ${ }^{7}$ Em 27 de setembro, reiterara que estavam "predestinados a la derrota o a la rendición". Em 15 de novembro, mais sensível, sua mãe respondia-lhe dizendo não esperar pronta rendição paraguaia, já que a guerra ganhava um novo caráter: "López en su casa será mas fuerte de lo que se imaginan". ${ }^{8}$

Sobretudo após o conhecimento do tratado secreto da Tríplice Aliança, publicado em Londres, em março de 1866, a invasão do Paraguai transformou a guerra ofensiva, de possível limitado respaldo popular em luta pela defesa da independência nacional, protagonizada sobretudo pelos camponeses proprietários, arrendatários e detentores de terras. O campesinato intuiria que, com a derrota, os aliancistas e os legionários colaboracionistas varreriam as conquistas obtidas sobretudo durante o "francismo", como realmente ocorreu.

Em Solano López: soldado de la gloria y del infortunio, apesar de seu indiscutível lopizmo, o coronel paraguaio Arturo Bray anota: "[...] es pouco probable que ninguno de los López - excepción hecha del Mariscal y hacia fines de la guerra - se haya atraído jamás el verdadero efecto del pueblo paraguayo". ${ }^{9}$

\section{Origens e objetivos da conspiração}

Desde sua designação como presidente, Francisco Solano López conheceu a oposição surda de facções proprietárias certamente interessadas em uma expressão mais 
direta no governo, a ser obtida através de seu afastamento do poder. Paradoxalmente, a principal liderança interna das forças liberais dissidentes seria Benigno López, o irmão caçula do presidente, envolvido na conspiração contra a eleição do primogênito dos López, quando do congresso de outubro de 1862, chamado após a morte de Carlos Antonio.

Após o fracasso da impugnação da candidatura de Francisco Solano López pelo deputado José María Varela, sob o argumento de proibir a Constituição que o país fosse patrimônio de uma pessoa ou família, a articulação foi reprimida com a prisão de envolvidos ou conhecedores da conspiração, com destaque para a condenação do padre Fidel Maíz a cinco anos de prisão e o fuzilamento do coronel Marín. Quando do começo da guerra, seguiam as represálias contra os aliados de Benigno López, relegado a uma sua propriedade do interior. ${ }^{10}$

As prisões ordenadas pelo governo, os boatos derrotistas e antilopiztas - registrados abundantemente na correspondência de Laurent-Cochelet -, a documentação governativa, são algumas das múltiplas fontes que fornecem indícios, ainda que indiretos, sobre a oposição entre as classes dominantes à guerra, antes e após sua deflagração. Uma oposição-defecção que parece se apresentar sobretudo como dissidência ao lopizmo ou a Solano López. ${ }^{11}$

Entretanto, a derrota teria consequência muito sérias para o Paraguai. Ela significaria o fim da independência nacional de fato do país e posição regional subordinada, com inevitável dependência comercial e econômica. A derrota alijaria as classes dominantes da determinação do poder e do governo, ainda que indireta, promovida através do lopizmo e do mariscal.

Entretanto, a derrota não determinava a perda dos bens dos proprietários, assegurados pelo programa das forças aliancistas e legionárias de reordenamento liberal radical do país. Os proprietários paraguaios teriam garantidos os privilégios de classe, mesmo perdendo a posição de senhores plenos em sua terra. Uma correta inserção na nova ordem asseguraria expansão subordinada dos antigos privilégios, devido à inevitável submissão das classes plebeias e camponesas que a vitória aliancista imporia.

A responsabilização do general Wenceslao Robles e do tenente-coronel Juan de la Cruz Estigarribia pelos tropeços militares no exterior $\square$ Paso de Los Libres, Corrientes, Uruguaiana e Riachuelo $\square$ não impediu a crescente desconfiança na direção militar e política do mariscal e no resultado da guerra. A mobilização geral do país, o retorno das tropas expedicionárias debilitadas e as importantes derrotas em Tuyuty teriam acelerado entre dignitários paraguaios a troca de opiniões sobre eventual rendição pactua$\mathrm{da}$, como meio de defesa dos interesses dos grandes proprietários.

À medida que se tornava clara a inevitabilidade da derrota, cresceria a consciência entre os proprietários da necessidade de salvar as castanhas do fogo. Porém, em muitos casos, essa "defecção" possivelmente se expressou apenas no círculo familiar restrito; em atos comportamentais pontuais; na adesão à boataria que invadiu o país; na procura de soluções pessoais etc. Comumente, não teria se transformado em conspiração ativa, por medo, por oportunismo, por falta de oportunidade etc. 
Benigno López, o mais jovem irmão do mariscal, teria dirigido ou participado com destaque nas primeiras discussões, devido à importância político-econômica da família López e, certamente, à segurança, ainda que relativa, que sua presença conferia às deliberações clandestinas. Benigno López estudara por dois anos na escola naval do Rio de Janeiro, tendo estabelecido relações privilegiadas com membros do mundo político da Corte. Ele mostrara-se desde sempre insatisfeito com a posição de "príncipe herdeiro" ocupada pelo primogênito. Ele fora acusado de ser o principal inspirador no "complô" de 1862 contra a eleição de Solano López como presidente.

Uma conspiração pelo fim da guerra deparava-se com graves dificuldades. Mesmo fortalecidos economicamente desde os últimos anos do "francismo" e revigorados política e socialmente pelo "lopizmo", os grandes proprietários sofriam de fragilidade estrutural diante do importante campesinato paraguaio. A centralização das tropas de extração camponesa solidárias na defesa do país tornava um golpe militar questão complexa. Os conspiradores sabiam que, se descobertos, pagariam com a vida.

\section{0 grande jogo}

As discussões conspirativas teriam se acelerado com as primeiras derrotas em solo pátrio, tendo como epicentro o pequeno círculo político oligárquico dominante constituído em torno da família López. As reticências com a guerra teriam fortalecido as desconfianças do mariscal em Benigno, nos dignitários de Asunción, em comandan- tes das forças armadas e em dirigentes das grandes famílias, que tinham muito a perder com uma resistência incondicional.

Sem contar com informações positivas, Solano López reteve precocemente em Humaitá a maior parte da comissão que partira da capital para presentear-lhe, em 25 de dezembro de 1867, espada de bainha de ouro e cravejada de diamantes, quando do transcurso do aniversário do juramento de independência paraguaio. $\mathrm{O}$ rico presente era oferta do "pueblo" da capital, ou seja, de suas classes pudentes. Não sabemos de outros eventuais objetivos da delegação e das possíveis discussões entre ela e Solano López.

Mesmo objeto de demonstrações de apreço por parte do mariscal, Saturnino Díaz Bedoya, presidente da comissão, também não recebeu permissão para voltar à Asunción, ficando retido em Humaitá, sem qualquer função. Bedoya, tesoureiro geral do Estado, casado com irmã do mariscal, integrava o círculo mais restrito do poder político e econômico do Paraguai, formado à sombra do poder da família López.

Quando, dois meses mais tarde, em 19 de fevereiro de 1868, os encouraçados imperiais ultrapassaram Humaitá, assustado e confuso, Bedoya procurou o bispo Manuel Antonio Palacios em "su casita de paja", no perímetro do Quartel General. Na entrevista, teria confessado o temor de que o grave revés militar motivasse algum sucesso "muy grave" em Asunción. Em um pestanejar de olhos, o bispo comunicou a Solano López as "preocupações" de Bedoya. ${ }^{12}$

A confidência de Bedoya teria radicalizado a desconfiança do mariscal nos dig- 
nitários da capital, com destaque para seus irmãos Benigno e Venancio López. Preso e interrogado pelo bispo Palacios e pelo general Vicente Barrios, também cunhado de Solano López, Bedoya, recomposto e certamente pouco pressionado, nada informou, à exceção de maldizeres sobre o mariscal e sua condução da guerra entre o "pueblo" de Asunción.

A entrevista de Bedoya com Palacios fora possivelmente motivada pelo medo de ser duramente punido, quando as eventuais iniciativas das autoridades de Asunción, motivadas pela ultrapassagem de Humaitá, fossem conhecidas pelo mariscal. Bedoya sabia muito mais do que revelara, quando interrogado, sobre as "articulações" entre as autoridades públicas na capital.

Mas o que realmente ocorreu - ou poderia ter ocorrido - em Asunción, que tanto assustava a Bedoya? Efetivamente, após a fácil superação, em 19 de fevereiro de 1868, da fortaleza de Humaitá, tida como a Sebastopol guarani, por flotilha imperial, que poucos danos sofreu na operação, encouraçados partiram em direção de Asunción, onde chegaram em 24 do mesmo mês, limitando-se a bombardear, de longa distância, por quatro horas, a cidade despovoada, sem lhe causar maiores danos. Paul de Cuverville, o novo cônsul francês, registrou que tão pequenos haviam sido os danos à cidade que "dos jornadas de albañilería serían más que suficientes para reparar los efectos de las treinta y tantas bombas y balas brasileras". ${ }^{13}$

\section{Estendendo a mão ao inimigo}

A ultrapassagem de Humaitá punha Asunción e o coração do Paraguai ao alcance da marinha imperial. A consolidação da consciência da inevitável derrota motivou que o núcleo conspirativo central capitalino tentasse, por primeira vez, em forma clara, ainda que com enorme indecisão, dissociar-se da resistência realizada em torno ao mariscal pelos segmentos populares. Nesse momento, à exceção de um destacamento de reserva de uns 1.200 homens, a capital despovoada abrigava sobretudo velhos, mulheres, crianças e estrangeiros.

Em Asunción, com a aproximação dos encouraçados, reuniu-se Conselho Consultivo da capital. Sob a direção do vice-presidente Domingo F. Sánchez, participaram da reunião o coronel Venancio López, comandante geral das armas da capital, seu irmão Benigno, o major Francisco Fernández, o juiz Bernardo Ortellado, o deão Eugenio Bogado, Carlos Riveros, Gumersindo Benitez e o padre Espinosa.

No conselho extraordinário, Francisco Fernández propôs que, vista a fragilidade das defesas da capital, sua artilharia não disparasse imediatamente contra os navios. Apesar de contar com o apoio da maioria dos presentes, a proposta não prosperou apenas devido à oposição do padre Espinosa, que conclamou a resistência, até o último "cartucho de pólvora", apoiado a seguir pelo vice-presidente Sánchez.

A falta de unanimidade desarticulou a iniciativa derrotista e registrou que as articulações conspirativas restringiam-se apenas a parte das autoridades capitalinas, com 
destaque para os irmãos López. A participação de Benigno e de Venancio punha sob suspeição suas irmãs Rafaela e Inocencia e os respectivos maridos, Saturnino Bedoya e o general Vicente Barrios, os dois então em Humaitá.

À noite, o vice-presidente chamou a uma nova reunião, na residência de Venancio López, por exigência do mesmo, que não ficara satisfeito com a decisão de resistência imediata. Desta vez, certamente consciente das consequências do ato e da fragilidade dos propositores, Carlos Riveros lembrou que não procedia a proposta de intimar os encouraçados, antes de abrir fogo, ao se tratarem de forças de nações em guerra. ${ }^{14}$

\section{o que queriam os conspiradores?}

A fragilidade das forças militares de Asunción impedia tentativa de golpe de Estado. Porém, a não hostilização dos couraçados abria caminho para comunicação direta com o inimigo e a eventual entrega da capital, com possíveis adesões no interior do país. E, como veremos, a ocupação de Asunción pelos aliados poderia ser seguida por pronunciamento militar em Humaitá que exigisse o afastamento do governo e saída do país de Solano López. Um arremedo de defesa, no caso de um desembarque imperial, comprometeria ainda mais a posição dos ex-membros do círculo íntimo do poder. $^{15}$

A articulação conspirativa sugeria ramificações mais complexas. Após a ultrapassagem de Humaitá, em 19 de fevereiro, a notícia foi conhecida no dia 21 na capital. Com a ultrapassagem, o mariscal ordenou a imediata transferência da administração civil do país e da população de Asunción para o povoado de Luque, a uns quinze quilômetros a oeste de Asunción. Luque estava ligada à capital pela ferrovia.

Na nova capital, a população estabeleceu-se, como pode, nos quartéis, nos alpendres das casas, nas ruas e nas duas amplas praças. Implementada em 22 de fevereiro, a transferência dificultava as articulações conspirativas possivelmente precipitadas com a aproximação da flotilha imperial. Em verdade, a instrução sobre o abandono de Asunción determinava no seu artigo quarto: "Cualquier persona que se encontrare [sic] en comunicación con el enemigo sufrirá la pena capital."16

No dia anterior, quando de reunião do corpo consular, o diplomata estadunidense Charles Washburn, apoiado pelo cônsul interino português José Maria Leite Pereira, opôs-se vivamente à transferência, em dissidência com os representantes da França e da Itália. O farmacêutico inglês G. F. Masterman, que presenciou aqueles sucessos, reconheceria que tal negativa devia-se sobretudo à esperança do diplomata estadunidense do pronto desembarque imperial em Asunción. ${ }^{17}$

Com experiência no jornalismo e estudos em leis, Charles Washburn partira para o Paraguai em fins de 1861, onde jamais conseguiu se ambientar, em sua primeira e última função diplomática, na simples posição de "ministro residente de Asunción". Ele manteve a legação estadunidense na então ex-capital, protestando diante do governo paraguaio pela ordem de transferência. 


\section{Refúgio dos conspiradores}

Charles Washburn fez mais. Escancarou as portas da sede diplomática para estrangeiros que temiam o possível bombardeio e desembarque aliancista, sabotando a ordem presidencial de transferência da população para Luque. Mais grave ainda, entre os refugiados encontravam-se personalidades envolvidas na conspiração logo desvelada, como os orientais Antonio de las Carreras e Francisco Rodríguez Larrata.

Em 16 de junho, também Leite Pereira, acompanhado de sua esposa, procurou asilo na sede estadunidense, já acusado, assim como o vice-cônsul português, de participarem no conluio. Apenas em 12 de julho, sob pressão do governo paraguaio, Washburn entregou às autoridades públicas diversos refugiados acusados de conspiração. Em 31 de julho, foi a vez de las Carreras e Francisco Rodríguez Larrata de serem presos ao perderem a proteção da legação. ${ }^{18}$

Com a fracassada proposta de acolhimento sem resistência da flotilha imperial e a oposição ao abandono de Asunción, Benigno e Venancio López; o deão Bogado; o major Francisco Fernández; o tesoureiro geral Saturnino Bedoya; os diplomatas Charles Washburn e Maria Leite Pereira tiveram suas iniciativas conspirativas plenamente reveladas.

Mas quando, precisamente, teria se constituído esse núcleo central conspirativo?

Não temos informação precisa sobre a constituição do comitê central conspirativo, que fracassou em sua iniciativa de 22 de fevereiro de 1868 . Zelosamente confeccionada e protegida pelo governo paraguaio, a do- cumentação referente à instrução dos inquéritos sobre a conspiração desapareceu após a guerra, nas mãos dos vencedores, sendo apenas parcialmente conhecida. ${ }^{19}$ Entretanto, podemos delinear o possível processo de constituição da conspiração.

A diplomacia estadunidense manteve-se no geral simpática à causa paraguaia, nem que fosse devido à disputa do espaço americano com a Inglaterra e à sua antipatia para com a ordem monárquica brasileira. Inicialmente, o legado estadunidense Charles Washburn contava com a plena confiança do mariscal. Em 11 de março de 1867, ele visitou o acampamento aliancista para explorar as condições para uma eventual mediação no conflito.

Em entrevista com o marquês de Caxias, foi informado sobre as exigências para estabelecer armistício e abrir negociações com o governo paraguaio. Entre elas, destacava-se o abandono de Francisco Solano López do país, condição à qual se opunha a chancelaria estadunidense. A Tríplice Aliança também exigia o desarmamento total do Paraguai.

Em geral, destaca-se a relativamente longa duraçãodaestada deCharles Washburn entre os aliancistas, que se alongou até 14 de março. Não temos informação sobre as discussões e as deliberações entre o diplomata e o marquês, conhecido por sua habilidade em turvas negociações, comumente facilitadas pelas importantes somas postas a sua disposição pelo Estado imperial.

A proposta para o fim da guerra avançada pelo marquês de Caxias teria sido difundida por Charles Washburn entre os mais altos dignitários paraguaios em dissi- 
dência com a guerra, quando de seu regresso a Asunción. Não é também impossível que importantes fundos tenham sido postos à disposição do diplomata por Caxias para facilitar a implementação das propostas do Império.

\section{Diplomacia dos patacões}

Era segredo de polichinelo nas tropas aliancistas os esforços do marquês para contatar e corromper segmentos dissidentes das classes dirigentes paraguaias. Em 1924, o general reformado José Luiz Rodrigues da Silva, que participara quando jovem do conflito, publicou suas Recordações da campanha do Paraguay. No livro, refere-se ao interesse aliancista na defecção de parte das classes dominantes paraguaias. ${ }^{20}$

$\mathrm{O}$ general lembrou que constava no exército, "à boca pequena, que o notável homem de guerra [Caxias], com as maiores cautelas" tentara "um dia corresponder-se com os vultos proeminentes da primeira camada da Capital"..$^{21}$ Já nas revoltas regenciais, Caxias mostrara-se extremamente hábil ao associar, para amaciar os inimigos, a pressão militar às ofertas de defecção mercenária.

Na correspondência aos seus familiares, o engenheiro militar Benjamin Constant registrou também aquelas tentativas, enganando-se sobre o interlocutor buscado pelo marquês. “O López não é suscetível de suborno, não se vende. O Caxias supôs que [...] com os imensos recursos de que o governo o rodeia podia assombrar o Paraguai. [...] $\mathrm{O}$ exército de moedas com que pretendia, como sempre, vencer o inimigo tem desaparecido esterilmente $[\ldots] .{ }^{\prime 22}$
Em 18 de agosto de 1867, quatro meses após a visita de Charles Washburn ao acampamento aliancista, o diplomata inglês G. Z. Gould realizou, em sentido contrário, a mesma viagem, com o mesmo objetivo. Ao visitar o acampamento paraguaio em Paso-pacú para promover a saída de cidadãos ingleses dispostos a deixar o país, apresentou também uma base de plano de discussão para pôr fim à guerra.

Retomando as exigências aliancistas, os principais pontos da proposta propunham a saída de Solano López do país, a entrega do governo ao vice-presidente, o desarmamento do Paraguai, a solução das desavenças por mediação. Debatida no alto comando paraguaio, a iniciativa certamente teve forte repercussão entre as classes dominantes do país, que desejavam ansiosas o fim da guerra.

Segundo C. Centrurión, próximo ao mariscal, para rejeitar a proposta, este último serviu-se das esperanças despertadas por mais uma sublevação na Argentina. ${ }^{23} \mathrm{O}$ fracasso da iniciativa do diplomata inglês consolidaria entre altos dirigentes e as classes dominantes paraguaias a visão de que o mariscal, tido como o grande responsável pela resistência incondicional, jamais se afastaria por bem do poder e do país.

Tradição histórica propõe que o "comitê revolucionário" formou-se em setembro ou outubro de 1867, após a rejeição do plano de paz de Gould. A reunião inaugural teria ocorrido na mansão da família López em Asunción com a presença dos diplomatas inglês Charles Washburn e português Leite Pereira; de Benigno, Venancio e, sobretudo, de dona Joana Carrillo López. La señora pre- 
sidenta era ativa personagem política do núcleo de poder lopizta, interessada em diversos negócios privados construídos à sombra do Estado.

\section{Filho do outro}

No encontro, a patriarca teria revelado que Solano López não era filho do falecido Carlos Antonio, mas produto de uma sua relação pré-matrimonial com seu riquíssimo padrasto e tutor, Lázaro Rojas, padrinho do mariscal. Essa estranha autoacusação, caso tenha ocorrido, teria sido feita para romper totalmente os laços consanguíneos do mariscal com o passado presidente e, parcialmente, com os seus quatros irmãos, facilitando moralmente a sua deposição. A proposta bastardia de Solano López era boato que corria solta havia muito no Paraguai. ${ }^{24}$

Os recursos que financiaram a conspiração - distribuído por Charles Washburn - teriam sido fornecidos por Benigno e por Saturnino Bedoya, tesoureiro geral do Estado, que teria para tal saqueado os cofres públicos. Washburn terminou sendo acusado de embolsar parte dos fundos que lhe foram entregues para a conspiração pelos paraguaios e, eventualmente, pelo marquês de Caxias, que sempre negou qualquer envolvimento nos fatos. ${ }^{25}$

Venancio López teria sido designado como responsável pela mobilização da guarnição da capital, por ele comandada. Ele sofrera diversas humilhações, por parte de seu irmão mais velho. Fora preterido quando da promoção de Robles ao generalato. Designado ministro da guerra e da marinha no primeiro ministério de López, fora substituí- do a seguir por seu cunhado Vicente Barrios, igualmente distinguido com chefia na campanha do Mato Grosso. ${ }^{26}$ Participavam com destaque no complô o bispo Manuel Palacios; o deão Eugenio Bogado; o português Leite Pereira; o inglês Alonzo Taylor; o italiano Simón Fidanza; os orientais Antonio de las Carreras e Francisco Rodríguez Larrata, entre outros.

Após a queda de Montevidéu, com centenas de orientais blancos, de las Carreras refugiara-se em Entre Ríos, partindo, em 22 de agosto, para Asunción, aonde chegou no início de dezembro, para colocar, a si e à imigração oriental blanca, à disposição de Solano López, no caso da invasão do Rio Grande do Sul, para chegar ao Uruguai. Entretanto, este destino não faria parte do plano de guerra do mariscal, que jamais se serviu dos serviços De las Carreras. ${ }^{27}$

De certo modo, a conspiração teria sido levada ao conhecimento do novo representante diplomático francês em Asunción, Paul de Cavalier de Cuverville [1838-1876], consultado em dezembro de 1867, portanto antes da passagem de Humaitá, sobre a posição de Napoleão III, que conhecera o mariscal, no caso da sua substituição. "Se han habituado incluso a la idea de un cambio en la presidencia, yo fui sondeado al respecto así como el Sr. Ministro de los Estados Unidos, por parte de Benigno López [...] sobre las intenciones del gobierno del Emperador en el caso en que los aliados entren en Asunción". Segundo o diplomata, os candidatos para a sucessão seriam José Bergés, Saturnino Bedoya e Benigno López. ${ }^{28}$

Ao contrário do seu antecessor, Cuverville era simpático ao Paraguai e a López, 
propondo alguns autores que teria informado eventualmente o governo total ou parcialmente sobre o que sabia do complô.

\section{A conspiração: da descoberta à repressão}

Sob o golpe da forte derrota sofrida com a ultrapassagem de Humaitá e ocupado com os preparativos para o abandono daquela fortaleza, Solano López teria postergado a repressão à conspiração desvelada pela reunião de 21 de fevereiro em Asunción. Eventualmente, teria esperado criar as condições para oficializar o rompimento com sua família e com representantes de destaque das classes sociais que constituíam a base tradicional do lopizmo e de seu poder.

Após abandonar Humaitá, em 3 de março, já no acampamento de San Fernando, o mariscal ditou, em 16 do mesmo mês, longa missiva ao vice-presidente exigindo explicações pela proposta de contemporização com o inimigo e "gratuitas acusaciones" lançadas pelo "pueblo" de Asunción contra sua pessoa. Também criticava Sánchez por encontrar-se sob a influência de seus irmãos e comunicava que Bedoya revelara o plano de constituição de "Gobierno revolucionário" em Asunción para cooperar com o inimigo.

Portanto, após o conhecimento das deliberações no conselho extraordinário de Asunción, Saturnino Bedoya fora possivelmente inquirido novamente, dessa vez certamente com maior decisão, confessando ao menos em parte o que calara inicialmente. A referência de Solano López à tentativa de constituição de governo revolucionário, na carta ao vice-presidente, registrava o conhecimento do plano subversivo e do núcleo central da conspiração.

Então com 73 anos, o vice-presidente respondeu ao mariscal assegurando sua plena fidelidade e explicando seu comportamento como produto da inexperiência e do "respeto que" havia "profesado siempre a todo lo que pertence a la casa y família" López. ${ }^{29}$ Sánchez seguiria o mariscal até o derradeiro combate de Serro Corá, em $1^{\circ}$ março de 1870, onde, doente e decrépito, foi morto por soldado imperial.

\section{Nossos interesses}

No relativo ao irmão Benigno, possivelmente cabeça da conspiração, o mariscal não determinou medida punitiva imediata. Limitou-se a ordenar, através do vice-presidente, segundo parece antes de se retirar de Humaitá, que ele viajasse para o acampamento de San Fernando, onde foi mantido sob estreita vigilância. Naquele então, Benigno encontrava-se na sua estância, no departamento de Villa Concepción, próximo à fronteira com o Mato Grosso, para onde se deslocara, possivelmente temendo a repercussão de seus atos. José Berges, Francisco Fernández e outros conspiradores também haviam sido convocados pelo mariscal. ${ }^{30}$

Ao chegar a San Fernando, Solano López teria inquirido Benigno sobre o seu comportamento, quando da discussão sobre como se comportar diante dos encouraçados inimigos que se aproximavam da capital. Segundo Centurión, recebera resposta que ilumina plenamente a forma de pensar e de agir de largas facções das classes proprietá- 
rias paraguaias, diante de derrota que viam como incontornável.

Benigno teria dito ao irmão: “- Señor, como no hemos tenido más noticias de Ud. o del ejército desde que Humaitá quedó sitiado por el enemigo, había creído llegado el momento de pensar y tomar alguna resolución tendiente a salvar nuestras personas y nuestros intereses." Após comentar com o coronel Caballero, presente ao colóquio, que o pueblo de Asunción se tornara "más negros que los mismo negros" [mais brasileiros que os próprios brasileiros], o mariscal determinou que Benigno vivesse em prisão domiciliar. $^{31}$

Por longo tempo secretário de Carlos Antonio López, Silvestre Aveiro serviu em igual posição ao mariscal quando da Guerra Grande, tendo atuado ativamente nos inquéritos de meados de 1868, no acampamento de San Fernando. Nas suas Memorias militares, escritas em 1880 e publicadas tardiamente, refere-se à inquisição ordenada pelo mariscal, sob a presidência do bispo Palacios, com sua participação, sobre o que "habia sucedido cuando el arribo de los encorazados a Asunción, a propósito de vacilaciones para hacer fuego sobre aquellos buques". A comissão inquirira igualmente a "impresión no favorabla" causada aos investigados pelo "encerramiento del ejército [paraguaio] por los aliados", quando do cerco de Humaitá.

$\mathrm{Na}$ ocasião, teriam sido acareados Benigno López, José Berges, Saturnino Bedoya, Francisco Fernández, Carlos Riveros, o juiz Bernardo Ortellado e o coronel Paulino Alén Benítez. Eles teriam ditado suas explicações, ocorrendo altercação entre Berges e Bedoya, já que o primeiro afirmou não ter estado no que o segundo apresentou como "simple conversación de família" sobre quem deveria suceder o presidente, caso ele fosse preso ou morresse ao tentar romper o cerco em que Humaitá se encontrava. Uma escolha que teria caído sobre Benigno López. ${ }^{32}$ As investigações teriam estacando já que os inquiridos mantiveram-se firmes na proposta de nada terem feito, senão discutir a eventual substituição do mariscal, no caso de sua prisão ou morte, o que não podia ser caracterizado como crime.

\section{A eclosão da repressão}

O acampamento militar paraguaio de San Fernando, nas margens do rio Tebicuary, teria pouca importância na história militar da guerra, sendo abandonado rapidamente devido às dificuldades postas pela região como local de defesa. Entretanto, ele tornaria-se célebre como cenário da eclosão do ciclo repressivo que se estenderia, com momentos de exacerbação, até o combate final em Cerro Corá, em $1^{\circ}$ de março de $1870 .{ }^{33}$

A grande repressão eclodiu, em junho de 1868, com a prisão de corneteiro da "escolta nacional" e do major Francisco Fernández, ajudante de ordens de Solano López, que haviam estado deliberando na cabana onde Benigno López se encontrava incomunicável, sobre o assassinato do mariscal. Preso e torturado, o major comprometeu como conspiradores ao padre Moreno e ao comandante Gómez. O trompa, ao contrário, confessara imediatamente que participara do projeto devido promessa de recompensa econômica. ${ }^{34}$ 
Segundo o corneteiro, o regicídio seria efetuado quando o mariscal saísse da missa. ${ }^{35}$ Os conspiradores fugiriam para as linhas inimigas nos cavalos do mariscal, então possivelmente os únicos bucéfalos paraguaios a receberem ração. Portanto, tratava-se de assassinato do presidente e não mais tentativa de golpe de Estado, com a tomada de controle das forças armadas e designação de um novo presidente para discutir a rendição. Os sucessos revelados agravaram a situação de Bedoya e de Benigno, que foram reduzidos à situação de prisioneiros.

Esperava-se certamente que a morte do mariscal acelerasse ou finalizasse a guerra, prestigiando os conspiradores junto ao alto comando aliancista. O que lhes garantiria participação no futuro ordenamento do país. $\mathrm{O}$ assassinato permitiria que a família López mantivesse suas propriedades, furtando-as às possíveis expropriações após o conflito. A fuga era necessária já que se esperava que a morte do mariscal ensejasse $o$ massacre dos prisioneiros pela tropa.

\section{Tudojá era sabido}

Não é igualmente impossível que a urdidura apenas descoberta fosse mera invenção para lançar repressão geral ao complô, conhecido, no mínimo, desde fins de fevereiro de 1868. Como vimos, já na carta de 16 de março ao vice-presidente, o mariscal registrara conspiração para formação de "gobierno revolucionário". Era imprescindível cortar pela raiz uma conspiração de lideranças conhecidas que, ao se infiltrar nos níveis superiores da administração civil e militar, criara situação de permanente desconfiança que minava a já decrescente capacidade de resistência paraguaia. ${ }^{36}$

Silvestre Aveiro, que participou diretamente na formação dos processos, apresenta sequência geral das delações que levaram às prisões, após a descoberta do plano para o assassinato do mariscal. Segundo ele, Benigno negou inicialmente qualquer conspiração, o que, associado à morte natural de Bedoya, devido aos maus tratos, teria levado a ponto morto as investigações.

Ainda que inseguro, Silvestre Aveiro propunha que fora a delação de Ramona Eguzquiza de Decoud, pelo presbítero Moreno, inculpado a sua vez pelo major Fernández, que fizera avançar a repressão. Em contato com conspiradores, a senõra falara de bilhetes conspirativos e de lista dos membros do Directorio Revolucionario, levando à prisão de mais de cem paraguaios e estrangeiros. Pela sua denúncia voluntária, Ramona obteve a liberdade.

Silvestre Aveiro afirmou que os conspiradores se conheciam apenas de "dos en dos" e que o "comite directivo" seria formado por doze membros, dois de cada nacionalidade representada no país. Entre os conspiradores se destacavam Benigno, Bedoya, Venancio, Berges, os diplomatas Washburn, Leite Pereira, entre outros. Reafirma que a base da conspiração era a guarnição de Asunción, "compuesta de varios cuerpos de jóvenes en instrucción, un batallón de marina y soldados viejos divididos en los cuarteles". 


\section{Mensageiro da traição}

Silvestre Aveiro lembrava que, nas "dos veces que fue al campo aliado", Washburn teria levado "notas o mensajes verbales para que Caxias aproximara un cuerpo de 10.000 hombres al Paso de Santa Maria, de Tebicuary, mientras López estaba encerrado", para facilitar a insurreição em Asunción. O que o marquês jamais fizera, talvez por desconfiar dos paraguaios, talvez contando apenas com o dilaceramento interno das classes dominantes do país. Ele acreditava que o plano conspirativo jamais se realizara por "falta de un hombre enérgico que se pusiera a la cabeza y por la esperanza que tenian en Caxias." ${ }^{37}$ Uma indecisão devida, em grande parte, às frágeis bases sociais da classe dominante paraguaia.

As prisões e torturas produziram delações em cadeia comprometendo em torno de duzentos "homens bons" de Asunción e do interior, sobretudo os "que ejercían el cargo de juez de paz y jefe de las milicias urbanas". Ou seja, os responsáveis pela administração das poucas reservas em homens e recursos da retaguarda que desempenhariam papel importante no caso de crise política geral determinada pelo afastamento ou pela morte do mariscal.

Em 16 de outubro de 1868, poucas semanas antes das grandes derrotas de dezembro, desde o acampamento de Pikysyry, Francisco Solano López deu a conhecer, oficialmente, à Nação e, sobretudo, às forças armadas, através de proclamação, a descoberta de conspiração de nacionais e estrangeiros contra o país, para livrá-lo à servidão e ao extermínio. No documento, em nenhum momento se citavam fatos precisos e, sobretudo, nomes, possivelmente devido ao caráter excelente dos conspiradores.

No manifesto, o mariscal propunha que, como a presidência, a guerra lhe havia sido imposta pelo Congresso, para que defendesse a "honra nacional". Informava que, sob a escusa de que o país estava "cansado com a guerra", conspiradores haviam saqueado o tesouro nacional em favor próprio e para financiar a traição à pátria. Lembrava que já fizera inutilmente proposições conciliadoras e rejeitava paz desonrosa para a nação. Reafirmava a decisão geral de morrerem, todos, na "santa cruzada" da defesa da "honra e da glória" nacionais. Propunha que, cumpridos os deveres para com a pátria, sob a proteção da Providência, se alcançaria finalmente um futuro grande e glorioso para o país. ${ }^{38}$

\section{Que fazer?}

Solano López reuniu prontamente o bispo Palacios, os generais Barrios, Resquín e Brugés e outros dignitários civis e militares, entre eles, Juan Cristóforo Centurión, para comunicar a conspiração que propunha apenas descoberta. Durante a reunião, afirmou que os conspiradores planejavam golpe de Estado e forneciam informações militares ao inimigo.

Os contatos com os dirigentes aliancistas através das legações envolvidas na conspiração eram episódicos, feito através da correspondência diplomática estadunidense e portuguesa, não sendo capazes de fornecerem informações táticas valiosas sobre as operações. Como veremos, os conspiradores 
foram acusados de sugerir caminho em direção a Asunción, contornando Humaitá. A proposta de entrega de informações militares permitia lançar sobre os traidores parte substancial da responsabilidade pelas sucessivas derrotas paraguaias.

O mariscal pediu conselho sobre como reprimir o complô, explorando a fidelidade dos inquiridos e comprometendo-os com a repressão. Segundo Centurión, ainda que temeroso, o general Francisco Isidoro Resquín foi o primeiro a falar, recomendando o uso da tortura, permitido pela legislação em vigor. $\mathrm{O}$ mariscal observara apenas que o procedimento não era usual no século em que viviam.

O bispo Palacios teria sugerido que os conspiradores fossem executados à medida que descobertos. O mariscal rejeitou com ironia a ideia, lembrando estar interessado no que pudessem contar. Essa proposta seria confirmada por Silvestre Aveiro, ainda que, segundo ele, Palacios a tivesse apresentado dias antes do natalício de Solano López, em 24 de julho. O bispo propusera que as investigações fossem encerradas "colgándose todos los encausados", devido também à eventualidade de um próximo ataque inimigo. ${ }^{39} \mathrm{~A}$ divergência registra os limites de depoimentos apoiados na memória, mesmo de testemunhas presenciais, sobre fatos realmente ocorridos.

A reunião concluiu-se com a constituição de seis tribunais militares. Resquín destacaria-se como inquisidor desapiedado, ao lado do padre Fidel Maíz, capelão geral do Exército, verdadeiro Torquemanda paraguaio. Preso no início do governo de Solano López, o padre obtivera sua libertação com longa e servil abjuração de todos seus pecados liberais. ${ }^{40}$ Mais tarde, denunciado, Palacios confessou ter sido informado da conspiração, pelo general Barrios, em Paso Pacú, não tendo, porém, em nada contribuído para seu desenvolvimento, além de manter o que sabia em segredo. $\mathrm{O}$ bispo seria fuzilado, em Pykysyry, em 21 de dezembro de 1868, junto com outros principais acusados, entre eles, Benigno López, Vicente Barrios, José Bergés, Eugenio Bogado, José Maria Leite Pereira, Paulino Alén. ${ }^{41}$

Após serem presas e enviadas a San Fernando, as autoridades da campanha envolvidas ou simpáticas à conspiração foram substituídas por de vinte a trinta velhos tenentes e alferes do exército de confiança do mariscal. Com o deslocamento de autoridades com compromissos pessoais e políticos dúbios, o poder do presidente, de claro sentido bonapartista-conservador, transformou-se em "ditadura militar patriótica", necessária à luta pela "salvação nacional", apoiada pelas classes plebeias e combatida pelas classes pudentes.

\section{0s refugiados da legação}

Em 20 de junho de 1868, como vimos, Gumersindo Benitez, então ministro das relações exteriores, solicitou a Charles Washburn que entregasse os refugiados na legação estadunidense que as investigações apontavam como envolvidos na conspiração. Em 12 de julho, o diplomata concedeu o pedido, à exceção dos orientais Antonio de las Carreras y Francisco Rodríguez Larrata, que perderam a proteção da legação apenas em 31 de julho. 
Em 6 de agosto, Gumersindo Benitez escrevia a Washburn comunicando-lhe que ele fora declarado "persona non grata" pelo governo, devendo iniciar os preparativos para abandonar o país. Na correspondência, afirmava que de las Carreras apontara sua participação no complô e revelara que a correspondência dos conspiradores com Caxias fora enviada com o selo diplomático português, através do comandante da canhoneira estadunidense Wasp, no ano anterior.

O plano conspirativo teria indicado caminho terrestre transitável para as forças aliancistas alcançarem Asunción, contornando Humaitá, como assinalado. A ocupação da capital seria o sinal para a tentativa de assassinato do mariscal. Acusava-se Washburn de negar-se a transferir a legação para Luque para facilitar a fuga dos conspiradores, quando da chegada da flotilha imperial, em fevereiro de 1868.

\section{Ditadura militar}

A campanha repressiva de San Fernando continuaria apenas com maior ou maior intensidade. Em janeiro de 1869, quando as tropas paraguaias procuravam refúgio na cordilheira e Asunción era ocupada, a vila de Concepción foi bloqueada por navios imperiais, o que motivou reuniões entre autoridades da região para discutir o que fazer, com eventuais propostas e iniciativas de rendição. Em março, quando autoridades do departamento foram presas e enviadas ao acampamento central, funcionários e proprietários do departamento refugiaram-se nos barcos inimigos. ${ }^{42}$
Benigno López possuía estância, familiares e estreitos laços com membros de famílias de destaque de Concepción. Uma dezena de inquisidores e lanceadores foram enviados ao departamento, com lista de acusados de participarem na conspiração. Pouco mais de quarenta homens e mulheres de famílias de destaque de Concepción, Guarambaré, Horqueta, Iponá, Villeta, etc. foram executados e expropriados. Antes da guerra, o departamento contaria com 11.176 moradores, à exclusão dos pueblos indígenas. $^{43}$

Com a repressão geral, Solano López rompia explicitamente com as classes dominantes e proprietárias paraguaias, que já depositariam substancialmente suas esperanças na vitória da Tríplice Aliança. Expressava-se plenamente o novo caráter do Estado paraguaio chefiado pelo mariscal, sustado, sobretudo, pelos segmentos camponeses e populares responsáveis pela resistência incondicional ao invasor. Classes que, no passado, conheciam situação de subordinação relativa sob a ordem bonapartista lopizta.

\section{Acampamento de prisioneiros}

Os apontados como conspiradores foram levados para o acampamento de San Fernando, onde foram interrogados e torturados, caso não confessassem imediatamente a participação nos fatos. Se muitos dos interrogados comprometeram-se apenas sob tortura, alguns teriam revelado a participação nos sucessos, desde os primeiros momentos. Entre eles, Venancio López, conhecido por sua falta de decisão e coragem. 
Tão numerosos foram os acusados chegados a San Fernando que se formou um miniacampamento de presos, agrupados comumente pela região de proveniência, pela atividade profissional, pela nacionalidade - civis, militares, sacerdotes, correntinos, italianos etc. Os prisioneiros portavam grilhões, mais ou menos pesados, segundo o grau de envolvimento, e eram atados pelos pés com tentos de couro.

$\mathrm{O}$ tratamento aos presos era duro. Eles dormiam sobre o chão, ao céu aberto, protegendo-se do sol, da chuva, do vento, do calor e do frio, com pequenas cabanas ou improvisadas tendas de couros, ponchos, mantas etc. Os mais infelizes ficavam expostos à inclemência do clima, duríssimo naquelas paragens. Muito dos detidos há mais tempo andavam quase nus - em situação não muito diferente à dos soldados paraguaios, é necessário reconhecer. Praticamente todos os presos eram do sexo masculino, comerciantes, de famílias proprietárias etc.

A alimentação era ainda mais escassa do que a já pouca consumida pela tropa. Em geral, era um ensopado com tiras de carne e alguns ossos, distribuído em uma gamela de madeira para cada cinco prisioneiros. Poucos dispunham de algo semelhante a uma colher para consumir o escasso alimento. A água fornecida era pouca, apesar do enorme calor durante o dia e da abundância do líquido disponível.

Os oficiais e soldados aliancistas presos eram mantidos em uma parte especial do acampamento. Também eles eram tratados com extrema dureza, ainda que gozando de alguns privilégios em relação aos presos políticos - podiam buscar água; possuíam objetos pessoais etc. Poucos prisioneiros de guerra sobreviveram ao fim do conflito. Os detentos que morriam executados ou de morte natural eram atirados ao rio. ${ }^{44}$

Paraguaios excelentes

Encontravam-se entre os presos os principais chefes da conspiração: Benigno e Venancio López; o bispo Palacios; José Bergés, ex-ministro das relações exteriores; Saturnino Bedoya, tesoureiro geral do país; o general Vicente Barrios, ex-ministro da Guerra e da Marinha; o general José Bruguez; o coronel Paulino Alén Benítez. Entre as poucas mulheres presas encontrava-se Juliana Insfrán de Martínez, esposa do coronel Francisco Martínez, responsabilizado pelo mariscal pela rendição das tropas de Humaitá.

Como vimos, foram igualmente acusados de conspiradores e presos comerciantes estrangeiros, europeus contratados pelo Estado, orientais e argentinos federalistas que haviam procurado refúgio no Paraguai etc., o cônsul português José María Leite Pereira; os orientais Antonio de las Carreras e Francisco Rodríguez Larrata; o capitão italiano Simón Fidanza; o jornalista estadunidense Porter C. Bliss; o farmacêutico inglês George Frederick Masterman.

Em suas Reminiscencias, Centurión relata que Bliss, durante sua prisão em Lomas Valentinas, escrevera opúsculo relatando longamente as responsabilidades de Charles Washburn na conspiração, editado a toque de caixa pela imprensa de guerra naquele acampamento. ${ }^{45}$ Masterman, arrolado como farmacêutico no exército paraguaio em 1861, escreveu a seguir o livro Sete anos de aventura no Paraguai. ${ }^{46}$ 
Em 12 de setembro de 1868, já em segurança, a bordo da canhoneira Wasp, Charles Washburn escreveu carta iracunda ao presidente Solano López, que se negara a recebê-lo. Na missiva, publicada na imprensa de Buenos Aires, tratava o mariscal de ustded $\mathrm{e}$ acusava-o de inventar a conspiração - "no creo que jamás haya habido ninguna conspiración" e de arrancar as confissões "bajo la tortura" ${ }^{47}$ Em 10 de dezembro de 1868, Bliss e Masterman foram igualmente evacuados em canhoneira estadunidense que aportara em Angostura, defesa e porto fluvial do acampamento paraguaio. Os diplomatas portugueses não teriam a mesma sorte..$^{48}$

Nos USA, Charles Washburn publicou, em 1871, uma History of Paraguay: with notes of personal observations and reminiscences of diplomacy under difficulties. O primeiro tomo, sobre a história do país, segundo afirma Centurión, teria sido composto a partir do trabalho que o jornalista estadunidense Porter C. Bliss, estipendiado pelo governo paraguaio para escrever a história nacional do país, redigira durante seu refúgio na legação e que jamais lhe fora devolvido. No segundo, o ex-diplomata defendia sua atuação no Paraguai, questionada ao retornar aos USA. Após aqueles sucessos, Washburn jamais voltou a desempenhar funções diplomáticas, vendo igualmente naufragar suas ambições políticas.

\section{Cristo do povo paraguaio}

O libelo acusatório do bispo Manuel A. Palacios, concluído em $1^{\circ}$. de dezembro de 1868, no acampamento de Pikysyry, pelos clérigos Justo Ramán e Fidel Maíz, cons- titui documento singular sobre os sucessos conspirativos e sobre a repressão iniciada no acampamento de San Fernando. ${ }^{49} \mathrm{O}$ uso da tortura, a ausência de defesa etc. têm desqualificado indevidamente essa rara e valiosíssima documentação como informação sobre os sucessos.

O documento de inculpação de Palácio registra explicitamente como elemento norteador da justiça em aplicação em San Fernando o princípio da autoridade plena do "príncipe", encarnação por direito divino do Estado e da Nação. O libelo registra o "regalismo" radical que sobrepunha, às eventuais obrigações eclesiásticas, os deveres do cidadão para com a pátria, para com a nação e para com o governo. Portanto, pecava-se contra a Igreja e contra deus, ao se pecar contra o governo.

Nessa visão pré-moderna de mundo, identificavam-se o caráter delitivo do desejo, a tentativa de sua realização e a própria realização. No catecismo judiciário de San Fernando, eram punidos o pensamento, o desejo e a ação contra a nação, contra o Estado, contra o governo e contra suas materializações, o "príncipe". O que circunscreve a ampla gama de atos caracterizados como crime de conspiração.

O libelo contra Palacios arrola como testemunha de acusação apenas o próprio acusado e o deão Eugenio Bogado, seu colaborador e confidente. Entre os crimes praticados pelo bispo estaria "comentar" com Bogado seu desacordo com o "gobierno de un solo hombre", que tenderia ao "absolutismo", e criticar as "leyes de la pátria y la administración nacional". "Hombre" era o eufemismo usado por Palacios para não no- 
minar a Solano López, mesmo quando confabulava com os seus mais próximos.

Palacios confidenciara também a Bogado a oposição à promoção, no púlpito do governo, pois o clero não devia envolver-se em política. Propusera que as "funciones eclesiásticas celebradas en los dias pátrios [...] no llevaban el verdadero espírito de la Religión", servindo apenas para agradar ao hombre. Afirmações que seriam crimes graves já que "Deus" proibia que se falasse mal do "príncipe" e a primeira obrigação do clero era obedecer sem reflexões ao governo.

Pecando por desejo

Acusou-se Palacios de revelar a Bogado - como ele próprio reconhecera - sua oposição a uma guerra que, para Palacios, irremediavelmente perdida, não interessava a ninguém, a não ser ao mariscal. Dizia que Solano López, "pela tenacidad de sostenerse", ou seja, de manter-se no poder, terminaria fazendo "matar a toda la gente antes que ceder nada". O bispo era acusado de aprovar em "privado" e rejeitar em "público" a proposta de G. Z. Gould. O plano rejeitado pelo mariscal previa, entre outros pontos, a saída López do país; a entrega do governo ao vice-presidente; o desarmamento do Paraguai; a solução das desavenças por mediação, como vimos. ${ }^{50}$

Para que a guerra chegasse ao fim, o bispo desejara a morte de Solano López, quando estivera doente - outro grave crime. Palacios revelara igualmente ao deão Bogado que desejava sobreviver ao conflito para "escribir [sobre] todos los defectos del hombre" durante aqueles terríveis tempos, mantendo para tal um diário.
O bispo não apenas pensara, mas falara e obrara contra o governo supremo, ao ter contatado "algunos de los principales de la revolución", que haviam procurado "inteligenciarse previamente con los atroces enemigos" para obrigar ao mariscal a sair do país. Ou seja, para fazer cumprir a principal exigência da Tríplice Aliança, apresentada por Washburn, em março, e por Gould, em agosto de 1867.

Tamanha era o seu desejo de por fim à guerra, "a cualquier modo", que aceitaria fazê-lo, nas suas palavras, "hasta perdiendo el ultimo calzón". Ou seja, mesmo aceitando as exigências mais leoninas. Nos planos revolucionários, urdidos "en el seno mismo del Ejército", seria ele que intimaria López a abandonar o país, devido a sua elevada autoridade religiosa, quando ocorresse "incidente que fuera desfavorable" às armas paraguaias. ${ }^{51}$

A inculpação de Palacios assinalou igualmente o enorme temor da repressão dos conspiradores. Tão perfeita fora a dubiedade do bispo que era visto como extremado lopizta, sendo desprezado por muitos antilopiztas por jamais obrar em favor da moderação de Solano López, apoiado em sua autoridade religiosa. Palacio foi inculpado de desejar a morte, mas não de conspirar contra a vida do mariscal.

O libelo condenatório conclui-se pedindo a morte, além da suspensão de Palacios de sua alta função eclesiástica. Exigia-se igualmente que Solano López, identificado pelos juízes como o verdadeiro Cristo paraguaio, nomeasse um novo bispo, para não deixar na orfandade a Igreja do país. Pouco faltava no documento para sugerir o nome do padre Fidel Maíz para o elevado cargo. 


\section{Perdoando a família}

Em um segundo libelo sumário, de 17 de dezembro de 1868, com o objetivo explícito de proceder a execução dos réus, quando se esperava livrar, talvez no dia seguinte, "la última batalla", o padre Maíz e seis outros "juízes" reafirmaram que o general Barrios, Benigno López e José Bergés seriam os principais membros do "comitê revolucionário", além do deão Eugenio Bogado, do cônsul português José Maria Leite Pereira, do coronel Vanancio López e outros.

No documento propunha-se que, tendo Venancio López mostrado "arrependimiento" desde o momento de sua prisão, recebera o benefício de não ser condenado à morte. Entretanto, o indulto de pouco lhe serviria - Venancio morreria, em fevereiro de 1870, devido aos maus-tratos, quando de marcha forçada em direção de Cerro Corá. ${ }^{52}$

Segundo o libelo, foram também indultadas pelo fratelo, Rafaela e Inocencia López, que mereciam a pena máxima, mesmo sendo "mujeres como son". Elas foram perdoadas por terem sido certamente arrastadas à traição pelos "perversos" maridos..$^{53}$ Mesmo torturado, diversas vezes, Benigno López negara-se terminantemente a reconhecer a participação nos fatos das irmãs e da mãe, confirmada por Venancio López e por José Berges. ${ }^{54}$

Ao ser notificado por seu cunhado que havia sido citado como conspirador, o general Barrios dirigira-se para sua moradia onde, com uma navalha na mão, entrou no quarto de Inocencia e cortou a própria garganta, antes de dizer a sua esposa, incriminando-a diante de um secretário: “Tú me haz querido ver de este modo." ${ }^{55}$ Barrios teria sobrevivido, já sem voz, sendo mais tarde fuzilado, como visto.

Registrando o nível radical de defecção da família López com a resistência paraguaia e uma indiscutível e despudorada capacidade de adaptação, as duas irmãs abandonaram com extrema rapidez a viuvez! Rafaela, viúva de Bedoya, casou-se com o coronel brasileiro Augusto de Azevedo Pedra, que conheceu em Cerro Corá. Desmentido o nome recebido na pia batismal, sua irmã Inocencia, viúva do general Barros, teria parido um bastardo do general Correa da Câmara, que também conheceu em Cerro Corá!

\section{0 sentido da repressão}

Apesar de algumas propostas extremadas e fantasiosas sobre o número das vítimas dos tribunais de sangue, os condenados e executados - fuzilados, lanceados etc. - ultrapassariam apenas o meio milhar, estimando-se também em talvez uns seiscentos prisioneiros políticos falecidos de causas naturais, devido a enfermidades, maus-tratos etc., como proposto. As vítimas oficialmente condenadas foram sempre do sexo masculino, fora exceções como as de Concepción. ${ }^{56}$

Por um lado, a mortandade geral do conflito certamente minorava a eventual impressão causada pela magnitude relativa das vítimas da repressão. Mil e duzentos mortos, entre os executados e falecidos devido aos maus-tratos, em quase dois anos $\square$ de junho de 1868 a março de $1870 \square$, causaria pouco impacto, considerando-se que não poucos confrontos militares secundários haviam tido baixas mortais iguais e superiores. 
A repercussão dos sucessos nos grandes jornais do Prata e da Europa, entre as classes proprietárias paraguaias e a seguir na historiografia especializada, deveu-se sobretudo ao caráter excelente das vítimas, à exceção das últimas, quando da conspiração de San Estanislao, nascida no interior da escolta do mariscal, nos últimos meses da guerra. ${ }^{57}$ Se nos combates morriam, além de alguns oficiais, sobretudo populares em geral anônimos, a repressão ceifou quase apenas dignitários do Estado, diplomatas, políticos, grandes proprietários, etc.

A repressão golpeou os envolvidos na conspiração e, possivelmente, quem foi informado sobre ela sem a denunciar. No sistema político paraguaio havia escassa margem para dissidências. Com o país invadido e a defecção entre os proprietários, a verbalização de insatisfação para com a direção político-militar foi possivelmente também assimilada à conspiração. Teriam sido denunciados alguns desafetos dos inquisidores e dos denunciantes.

A tortura e a execução quase geral dos ajuizados não podem ser tratadas como decisões individuais terríveis, nascidas das idiossincrasias de ditador sanguinário ou do poder autoritário, como proposto. ${ }^{58}$ Elas foram indiscutivelmente reação à defecção de núcleos centrais das classes dominantes e à tentativa de constituição de um novo polo de poder. Elas tiveram objetivos políticos e foram dirigidas contra segmentos sociais precisos, contando com importante apoio entre a população plebeia. Foi fenômeno histórico que deve ter suas raízes e consequências político-sociais desveladas e compreendidas.
A conspiração aprofundara e organizara a oposição de facções da classe dominante à defesa contra os invasores, em implícita-explícita aliança com o inimigo nacional. Ela registrara, organizara e radicalizara o fim do contraditório consenso nacional e procurara enfraquecer e substituir a autoridade do Estado, ao vê-lo dissociar-se de sua função de expressão política das classes dominantes, mesmo indireta. Estabelecendo-se como "quinta coluna", a conspiração minou poderosamente desde o interior a resistência ao invasor, levando a desconfiança e a intranquilidade a suas filas. Mesmo indiretamente, contribuiu ao esforço militar aliancista. $^{59}$

\section{Terror como arma}

Já não mais contando com o consenso das classes dominantes para a resistência ao inimigo, o núcleo governativo reunido em torno de Solano López serviu-se da repressão para neutralizá-las através do medo à repressão desapiedada. As torturas, os maus-tratos, as execuções, atos duros e explícitos, buscavam pôr fim à conspiração e combater o perigo crescente do colaboracionismo, exacerbado pelo avanço do inimigo no território nacional.

A repressão lopizta servia-se do terror como desesperado recurso para impor sua hegemonia às classes dominantes - terror no sentido político-sociológico tradicional. Ou seja, tentativa de imobilização de facções sociais pelo medo de represálias duríssimas. Nesse sentido, o terror lopizta aproxima-se ao "terror revolucionário" e "contrarrevolucionário", utilizado na Revolução Francesa; 
ao terror dos colonialistas contra as populações submetidas; ao terror vermelho e branco, praticado na Revolução Russa etc.

O general Rodrigues da Silva descreveu os frangalhos humanos com que as tropas imperiais depararam-se, nos últimos momentos da campanha das Cordilheiras, devido à falta de recursos e à repressão lopizta. "De Capivary em diante, começamos a encontrar pelo caminho gente de Lopez, degolada ou lanceada por sua ordem severa [...]." ${ }^{\prime 60}$ Com sensibilidade política, o velho general sugere que, com a "exposição dos cadáveres recentes", talvez o mariscal procurasse pôr fim aos esforços de Caxias em "minar-lhe, com diplomacia" [sic] sua autoridade e governo. ${ }^{61}$

Do ponto de vista da resistência, a repressão à conspiração era uma necessidade, já que ela causara importantes danos à luta contra os invasores, ao lançar a desconfiança entre e sobre os administradores civis e os oficiais militares, que Solano López não substituiu plenamente - e não podia substituir - por indivíduos originários dos segmentos populares e camponeses comprometidos com a resistência.

\section{Figura ambígua}

Mesmo quando se transformara na principal referência da resistência popular e camponesa contra o invasor, separando-se e opondo-se objetivamente às classes proprietárias que representara anteriormente, Solano López seguiu comungando com os princípios socialmente oligárquicos tradicionais. Contradição que ajuda a compreender o seu caráter ambíguo nos sucessos históricos que protagonizou e algumas indiscutíveis limitações da resistência.

Francisco Solano López compreendia a defesa incondicional do país como luta por manter-se no poder, por defesa da honra da pátria, pela glória sua e do país, etc. Comandou a resistência camponesa sem jamais se transformar em um general popular, ao igual que um José Artigas, um Emiliano Zapata etc. Realidade que se expressaria plenamente na transferência como propriedade privada, através de falsa venda, para sua companheira e seus filhos, de imensas porções dos territórios em litígio. Os "horizontes" político-sociais de Francisco Solano López eram "aqueles de sua história, de suas funções e de sua classe", na formulação de Eric Hobsbawn sobre a impossibilidade das monarquias esclarecidas de dirigirem a revolução burguesa. ${ }^{62}$

A repressão mostrou-se como iniciativa racional, desde o ponto de vista da resistência incondicional, já que alcançou alguns dos objetivos perseguidos. Não foi, efetivamente, significativa a adesão organizada ao inimigo, após a primeira destruição do exército paraguaio, no final da campanha de Pykysyry, em fins de 1868. O abandono da resistência por segmentos da população e a colaboração crescente de autoridades paraguaias com os invasores assumiriam maior importância apenas quando da campanha das Cordilheiras.

Em agosto de 1869, com governo "provisório" legionário estabelecido em Asunción, os "pueblos de San José, Ajos (hoy Cnel. Oviedo), Villa Rica, Hyaty y otros adhirieron al nuevo orden, bajo cierta protección 
del ejército brasileño". ${ }^{63}$ Sobretudo quando da retirada em direção a Cerro Corá, o pouco que restava de forças e autoridade a Solano López entrou em processo de dissolução, perdendo o próprio exercício do terror poder performativo, devido à incapacidade do governo de exercer sua autoridade sobre regiões sob controle aliancista.

\section{Apoio popular ao terror}

A repressão iniciada em San Fernando teria contato com o pleno apoio das tropas plebeias do exército paraguaio. Em meados de 1867, o major prussiano Max Von Versen driblou a vigilância das sentinelas aliancistas para ir assistir a guerra junto às tropas paraguaias, como observador independente. É também possível que esperasse obter um elevado posto de comando, devido à sua experiência na guerra autro-prussiana de 1866, o que não ocorreu. Em verdade, Von Versen jamais foi verdadeiramente recebido pelo mariscal.

Acolhido inicialmente com condescendência, devido à perseguição que sofrera por parte do Império, Von Versen terminou em situação equivalente a dos prisioneiros políticos, sob a ameaça de execução, sem lhe ter sido jamais imputada qualquer acusação. Escapou com vida ao fugir, no final dos combates de Lomas Valentinas, junto com o major brasileiro Cunha Matos. Von Versen escreveu uma História da guerra do Paraguai de indiscutível valor, em geral simpática para com Solano López, que via como demiurgo da intransigente defesa do país, sem compreender as raízes sociais profundas da resistência paraguaia.
Von Versen conviveu com dezenas de detentos políticos, registrando que os "hombres malos", como eram denominados, provinham quase todos das "classes melhores da população". Propôs que Solano López colocara "propositalmente" "na primeira linha da vanguarda", o "batalhão $\mathrm{n}^{\circ} 40^{\prime}$, recrutado em Asunción, "três vezes aniquilado e três vezes reconstituído", devido à sua "prevenção" "contra as pessoas de espírito cultivado", que crescera "à medida que se acentuava o infortúnio de seu desgoverno" ${ }^{64} \mathrm{Na}$ capital se concentravam os segmentos sociais de raízes étnicas e culturais espanholas. O farmacêutico inglês George Masterman registrou igualmente que as mulheres aprisionadas "pertenecían a la mejor clase de la sociedad" ${ }^{65}$

\section{Guaranis versus espanhóis}

Von Versen propôs resposta para a pergunta sobre o conteúdo social do terror lopizta, em geral não plenamente verbalizada na época ou após ela. Ou seja, por que as terríveis ondas repressivas jamais conheceram oposição ou despertaram antipatia entre a tropa e a população paraguaia? Para o major prussiano, a falta de empatia dos soldados paraguaios para com as centenas de martirizados devia-se, "mais do que tudo", à "antipatia de raças".

Sob a proposta da oposição de raças, Von Versen referia-se claramente ao sentido classista da contradição entre os segmentos camponeses "guaranitizados" e as classes dominantes "espanholizadas", incluindo na última categoria os europeus natos: "Os guaranis [soldados] assistiam com 
disfarçado mas natural prazer, a completa eliminação dos espanhóis que os tinham escravizados." ${ }^{66}$ Soldados, cativos, serviçais delataram membros das classes proprietárias como conspiradores. As deserções iniciais nas forças armadas paraguaias seriam, sobretudo, de filhos e membros das famílias proprietárias. ${ }^{67}$

Um comportamento que, quase meio século antes, apoiara e garantira a vitória da repressão, contra os mesmos segmentos sociais, quando da Grande Conspiração de 1820. ${ }^{68}$ A grande diferença entre as repressões de 1820 e de 1868-70 é que, no primeiro caso, o ditador Francia, em geral acusado de sanguinário, poupara a vida dos conspiradores, liquidando-os [e a suas famílias] socialmente, ao expropriar-lhes as propriedades.

Ao contrário do ocorrido sob o francismo, Solano López submetera os conspiradores à tortura, a ingentes sofrimentos e à morte, tudo publicamente. Sobretudo porque, naquele então, essas eram as únicas ações efetivamente capazes de impor terror aos dissidentes, devido à crescente dissolução do Estado lopizta e à grande possibilidade de que não sobrevivesse ao conflito. Entretanto, os bens dos condenados foram igualmente expropriados.

A dizimação do exército de linha no exterior e na batalha de Tuyuty teria ceifado fortemente seus elementos "espanholizados", que constituíam igualmente instrumento de imposição da ordem lopizta sobre as classes subalternizadas. A partir de então, as tropas foram restabelecidas sobretudo com os milicianos dos partidos do interior, fortalecendo o caráter camponês e a língua guarani como meio de comunicação nas forças armadas. Após alguns meses no acampamento paraguaio, o major Max Von Versen, que dominava com dificuldade o espanhol, já havia "aprendido bastante o guarani" ${ }^{69}$

Em La politique du Paraguay, comparando a resistência paraguaia à Revolução popular de 1830 na França, Claude de la Poepe propõe que a conspiração dava-se em "proveito exclusivo da burguesia, sem nenhum benefício para o povo, que continuava", "concentrado no campo" de batalha, "em redor do chefe que tinha elegido, versando seu sangue pela defesa do território nacional" ${ }^{70}$

\section{Abstract}

The great conspiracy against the continuation of the war, discovery and repressed in the San Fernando camp, in mid-1868, is presented as a product of the mariscal paranoid imagination by his detractors, and justified by its supporters, despite the abstract nature of judgments, without the right to defense, and the widespread use of torture. The paper presents interpretations about the meaning of the profound social indisputable conspiracy organized around the López family and the harsh repression that motivated.

Keywords: Blood courts of San Fernando. Paraguayan War. Terror and politics. 


\section{Resumen}

La gran conspiración contra la continuidad de la guerra, descubierta y reprimida en el campamento de San Fernando, en mediados de 1868, es presentada tradicionalmente como producto de la imaginación paranoica del mariscal, por sus detractores, y justificada por sus defensores, a pesar del carácter sumario de los juicios, sin derecho a defensa, y del amplio uso de la tortura. El artículo presenta interpretaciones sobre el sentido social de la indiscutible conspiración organizada alrededor de la familia de López y de la dura represión que ella motivo.

Palabras clave: Guerra del Paraguay. Tribunales de Sangre de San Fernando. Terror y Política.

\section{Notas}

1 VERSEN, Max Von. (1833-1893). História da guerra do Paraguai. Belo Horizonte: Italiana; São Paulo: Edusp, 1976. p. 131 et seq.; GODOI, Juan Silvano. El fusilamiento del Obispo Palacios y los tribunales de sangre de San Fernando. Documentos históricos. Asunción: El Lector, 1996.

2 VERSEN. História da guerra do Paraguai. ob. cit., p. 102 et seq ; GODOI, Juan Silvano. El fusilamiento del Obispo Palacios [...]. ob. cit., p. 52.

3 GODOI, Juan Silvano. El fusilamiento del Obispo Palacios [...]. ob. cit., p. 39.

4 O'LEARY, Juan E. El Mariscal Solano López. 3. ed. Asunción: Casa America, 1970. p. 435.

5 RIVAROLA, Milda. La Resistencia a la Guerra Grande. Estudios Paraguayos, U. C., Departamento de Ciencias Sociales, Centro de Estudios Antropológicos, vols. 26 y 27, n. 1 y 2, Asunción, 2008-2009, p. 179-189. www.portalguarani.com/obras_autores_detalles.php?id_obras $=13571$.

6 VERSEN. História da Guerra do Paraguai. ob. cit., p. 102.
7 CARRETERO, Andrés. (Org.). Correspondencia de Dominguito en la Guerra de Paraguay. Buenos Aires: El Lorraine, 1975. p. 41.

8 Id. ib., p. 61 e 77.

9 BRAY, Arturo. Solano López: soldado de la gloria y del infortúnio. 3. ed. Asunción: El Lector, 1996.

${ }^{10}$ CENTURIÓN, J. C. Memórias [...]. ob. cit. p. 75; CAPDEVILLA, Luc. Una guerra total: Paraguay, 1964-1870. Ensayo de historia del tempo presente. Buenos Aires: Sb, 2010. P. 302 et passim.

${ }^{11}$ Capdevilla, L. Una guerra total. ob. cit. p. 281-427.

${ }^{12}$ CENTURIÓN, Juan Crisóstomo. Memorias o reminiscencias historicas sobre la Guerra del Paraguay. Asunción: El Lector, 1987. p. 289.

${ }^{13}$ MASTERMAN, George Frederick. Siete años de aventuras en el Paraguay. Traduc. D. Lewis. Buenos Aires: Americana, 1870. p. 200; CAPDEVILLA, Luc. Una guerra total. ob. cit. p. 441.

${ }^{14}$ MASTERMAN, George Frederick. Siete años [...]. ob. cit. p. 200.

${ }^{15}$ Loc. cit.

${ }^{16}$ RUBIO, Mercedes. Los papeles de Burton: los secretos de la guerra de la Triple Alianza. Buenos Aires: Imago Mundi, 2012. p. 60.

${ }^{17}$ CENTURION. Memorias [...]. ob. cit., p. 288; TAUNAY, Alfredo D'Escragnolle, Visconde de. Diário do Exército: Campanha do Paraguai (1869-1870). Rio de Janeiro: Biblioteca do Exército, 2002. p. 17; MASTERMAN, George Frederick. Siete años de aventuras en el Paraguay. Traduc. D. Lewis. Buenos Aires: Americana, 1870. p. 199.

${ }^{18}$ VIDAURRETA DE TJARKS, Alicia. Al Margen de la Guerra del Paraguay. Memoria Academica. Trabajos y comunicaciones, 1968, 18, p. 251. www.memoria.fahce.unlp.edu.ar/art_revistas/ pr.1060/pr.1060.Pdf.

${ }^{19}$ SILVEIRA, Mauro César. A adesão fatal: a participação portuguesa na Guerra do Paraguai. Porto Alegre: EdPuc, 2003. p. 258.

${ }^{20}$ SILVA, José Luiz Rodrigues da. Recordações da Campanha do Paraguay. São Paulo: Melhoramentos, [1924]. $128 \mathrm{p}$.

${ }^{21}$ Id. ib., p. 92.

${ }^{22}$ LEMOS, Renato (Org.). Cartas da guerra: Benjamin Constant na campanha do Paraguai. Rio de Janeiro: IPHAN; Museu Casa de Benjamin Constant, 1999. p. 119; MAESTRI, Mário. Cartas desde o front da Guerra do Paraguai. Revista Territórios e Fronteiras, v. 2, n. 1, jan./jun. 2009. PPGH do ICHS/UFMT.

${ }^{23}$ CENTURIÓN. Memorias [...]. ob. cit., p. 245-246.

${ }^{24}$ BRAY, A. Solano López. ob. cit., p. 87. 
${ }^{25}$ RIVALORA, Milda. La Resistencia a la Guerra Grande. ob. cit., nota 19; POEPE, Claude de la. La politique du Paraguay: identité de cette politique avec celle de la France et de la Grande-Bretagme dans le Rio de la Plata. 2. ed. Paris: E. Dentu, 1869. p. 276.

${ }^{26}$ CAPDEVILA, 1. Uma guerra total [...]. ob. cit. p. 300, 302 et passim.

27 VIDAURRETA DE TJARKS, Alicia. Al Margen de la Guerra del Paraguay. Trabajos y comunicaciones, 1968, 18, p. 243 et seq. www.memoria.fahce. unlp.edu.ar/art_revistas/pr.1060/Pr.1060.pdf; MAESTRI, Mário. O Plano de Guerra Paraguaio em uma Guerra Assimétrica: 1865. Revista Brasileira de História Miltiar, [2013, no prelo]. www. historiamilitar.com.br.

${ }^{28}$ CAPDEVILLA, Luc. Una guerra total. ob. cit., p. 432.

${ }^{29}$ CENTURIÓN. Memorias [...]. ob. cit., p. 290.

${ }^{30}$ AVEIRO, Silvestre. Memorias militares. Asunción: El Lector, 1998. p. 59.

31 CENTURIÓN. Memorias [...]. ob. cit., p. 309.

32 AVEIRO, Silvestre. Memorias militares. ob. cit., p. 60 .

${ }^{33}$ GODOI. El Fusilamiento del Obispo Palacios [...]. ob. cit., p. 52.

${ }^{34}$ AVEIRO, Silvestre. Memorias militares. ob. cit., p. 65.

35 Loc. cit.

36 SILVEIRA, Mauro César. A Adesão fatal. Ob. cit. p. 242 et seq.

37 POEPE, Claude de la. La politique du Paraguay: identité de cette politique avec celle de la France et de la Grande-Bretagme dans le Rio de la Plata.2 ed. Paris: Dentu, 1869.

38 ARECES, Nidia R. Terror y violencia durante la Guerra del Paraguay: 'La Masacre de 1869 y las familias de Concepción. European Review of Latin American and Caribbean Studies 81, October 2006. p. 45. www.cedla.uva.nl/50_publications/pdf/revista/81RevistaEuropea/81ArecesISSN-0924-0608.pdf.

39 AVEIRO, Silvestre. Memorias militares. ob. cit., p. 67.

${ }^{40}$ GODOI. El Fusilamiento del Obispo Palacios [...]. ob. cit., p. 17 et seq.

41 AVEIRO, Silvestre. Memorias militares. ob. cit., p. 71.

${ }^{42}$ RIVAROLA, Milda. La Resistencia a la Guerra Grande. ob. cit. nota 34.

43 ARECES, Nidia R. Terror y violencia durante la Guerra del Paraguay. ob. cit., p. 47.

${ }^{44}$ VERSEN. História [...]. ob. cit., p. 132 et seq.

${ }^{45}$ BLISS, Porter Cornelio, Historia secreta de la misión del ciudadano norteamericano Charles A. Washburn, cerca del gobierno de la república del Paraguay. Por el ciudadano americano, traductor titular (In Partibus) de la misma misión [...]". Asunción: Imprenta Oficial, [1868]. 323 p.

${ }^{46}$ MASTERMAN, George Frederick. Siete años de aventuras en el Paraguay. Traduc. D. Lewis. Buenos Aires: Americana, 1870.

47 VIDAURRETA DE TJARKS, Alicia. Al margen de la guerra del Paraguay. Trabajos y comunicaciones, 1968, 18: 251. www.memoria.fahce.unlp.edu. ar/art_revistas/pr.1060/pr.1060.pdf

${ }^{48}$ CENTURIÓN. Memorias [...]. ob. cit., p. 326.

${ }^{49}$ ROMAN, Justo; MAÍZ, Fidel. Campamento de Pikyrysyry, Diciembre $1^{\circ}$ de 1868. GODOI. El fusilamiento del Obispo Palacios [...]. ob. cit., p. 73-95.

${ }^{50}$ CENTURIÓN. Memorias [...]. ob. cit., p. 246.

${ }^{51}$ GODOI. El Fusilamiento del Obispo Palacios [...]. ob. cit., p. 123.

${ }^{52}$ CENTURIÓN. Memorias [...]. ob. cit., p. 431.

${ }^{53}$ GODOI. El Fusilamiento del Obispo Palacios [...]. ob. cit., p. 127.

54 AVEIRO, Silvestre. Memorias militares. ob. cit., p. 69.

55 Loc. cit.

56 GODOI. El Fusilamiento del Obispo Palacios [...]. Ob. cit., p. 55.

57 CENTURIÓN, J. C. Memorias [...]. Ob. cit. p. 407.

58 ARECES, Nidia R. Terror y violencia durante la guerra del Paraguay. Ob. cit., p. 13 et. seq.

59 SILVEIRA, Mauro César. A adesão fatal. Ob. cit., p. 242 et seq.

${ }^{60}$ SILVA. Recordações da campanha do Paraguay. Ob. cit., p. 91.

${ }^{61}$ Loc.cit

${ }^{62}$ HOBSBAWM, E.J. L'Ère des Révolutions. Paris: Fayard, 1969. p. 37.

${ }^{63}$ RIVAROLA, Milda. La Resistencia a la Guerra Grande. Ob. cit., nota 35.

${ }^{64}$ VERSEN. História da guerra do Paraguai. Ob. cit., p. 112-113.

65 GODOI. El Fusilamiento del Obispo Palacios [...]. Ob. cit., p. 40.

${ }^{66}$ VERSEN. História da guerra do Paraguai. Ob. cit., p. 134.

67 RIVAROLA, Milda. La Resistencia a la Guerra Grande. Ob. cit.

${ }^{68}$ WHITE, Richard Alan. La primera revolución popular en America: Paraguay (1810-1840). 2. ed. Asunción: Carlos Schauman, 1989.

${ }^{69}$ VERSEN. História da Guerra do Paraguai. Ob. cit., p. 145.

70 POEPE, Claude de la. La politique du Paraguay . Ob. cit., p. 273. [traduzimos]. 